\title{
ПРОБЛЕМИ ФОРМУВАННЯ ПРАКТИЧНИХ НАВИЧОК НА КАФЕДРІ ПРОПЕДЕВТИКИ ПЕДІАТРІЇ В УМОВАХ ВИКОРИСТАННЯ КРЕДИТНО-МОДУЛЬНОЇ СИСТЕМИ
}

\author{
К. А. Калашнікова, О. О. Старець, Н. О. Нікітіна \\ Одеський національний медичний університет
}

\section{PROBLEMS OF FORMING THE PRACTICAL SKILLS AT THE CHAIR OF PROPEDEUTICS OF PEDIATRICS IN TERMS OF USING THE CREDIT- MODULAR SYSTEM}

\author{
K. A. Kalashnikova, O. O. Starets, N. O. Nikitina \\ Odesa National Medical University
}

\begin{abstract}
У статті проаналізовано викладання пропедевтики педіатрії за останні тридцять років. Окреслені проблеми формування навчальної діяльності на сучасному етапі.
\end{abstract}

The article analyzed the teaching of Pediatrics Propedeutics for the last thirty years. The problems of forming of the educational activity at contemporary stage are considered.

\begin{abstract}
Присвячується пам'яті лауреата Державної премії України в галузі науки і техніки, професора, доктора медичних наук I. Л. Бабія, завідувача кафедри пропедевтики педіатрії з 1991 до $2011 p$.
\end{abstract}

Вступ. Впровадження кредитно-модульної системи організації навчального процесу в нашій країні, успішна реалізація реформ у сфері охорони здоров'я можливі лише за умови забезпечення якісної практичної підготовки спеціалістів $[1,2]$. Основною метою викладання у вищих медичних навчальних закладах є набуття студентами вмінь, які складаються з отриманих теоретичних знань та практичних навичок, відповідних вимогам освітньо-кваліфікаційної характеристики і освітньо-професійної програми підготовки фахівців. Питанням набуття студентами практичних навичок, вмінь надається значна увага [3]. У документах міжнародних семінарів і матеріалах проекту “Налаштування освітніх структур у Європі” (Tuning Educational Structures in Europe TUNING) експерти визначають пріоритетними принципи орієнтації на результати навчання, поширення соціального партнерства освіти зі сферою праці [4]. Розвиток сімейної медицини в Україні потребує якісної підготовки студентів з питань педіатрії.
Основна частина. Аналіз результатів навчання при організації навчального процесу за кредитно-модульною системою на нашій кафедрі протягом 5 років висвітлив деякі проблеми, протиріччя та недоліки.

Нами зроблено аналіз структури академічних годин 3 пропедевтики педіатрії за останні 30 років, 3 1981 по 2011 рік. На рисунку 1 представлена динаміка аудиторних академічних годин, що виділені для проведення практичних занять та лекцій з пропедевтики педіатрії. Згідно з графіком, кількість аудиторних годин поступово збільшувалась 3140 годин (1981 р.) до 240 годин (1993 р.), потім знову зменшилась до 140 в 2011 р. При цьому кількість годин 3 практичних занять в 2011 р. значно знизилась - до 100 годин.

Якщо кількість лекцій скоротилась 372 годин (1993 р.) до 40 годин (2011 р.), тобто на 56 \%, i, за нашою думкою, тепер достатня, то зниження годин по практичних заняттях є дуже проблематичним, тому що кількість годин, відведених на проведення

() К. А. Калашнікова, О. О. Старець, Н. О. Нікітіна 
практичних занять, зменшилась на 60 \% (3 1993 по 2011 р. відмічається скорочення з 168 годин до 100 годин).

При кредитно-модульній системі навчання велике значення надається самостійній роботі студентів
(CРС). На рисунку 2 видно, що програми 3 пропедевтики педіатрії у 1981, 1983, 1993 роках не регламентували кількість годин на самостійну роботу студентів. В 1988 р. на СРС виділялося 46 годин (22,6 \% загальної кількості академічних годин). 31996 до

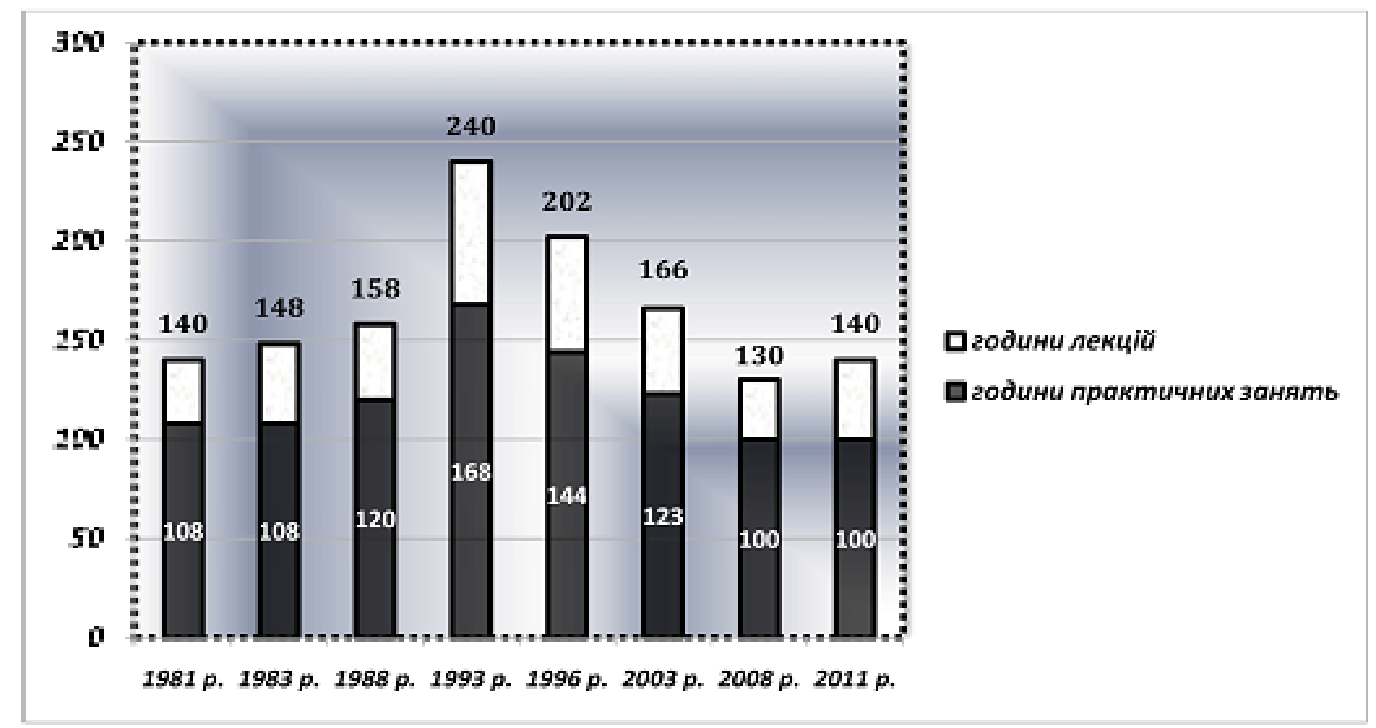

Puc. 1. Динаміка академічних годин (практичні заняття + лекції), години.

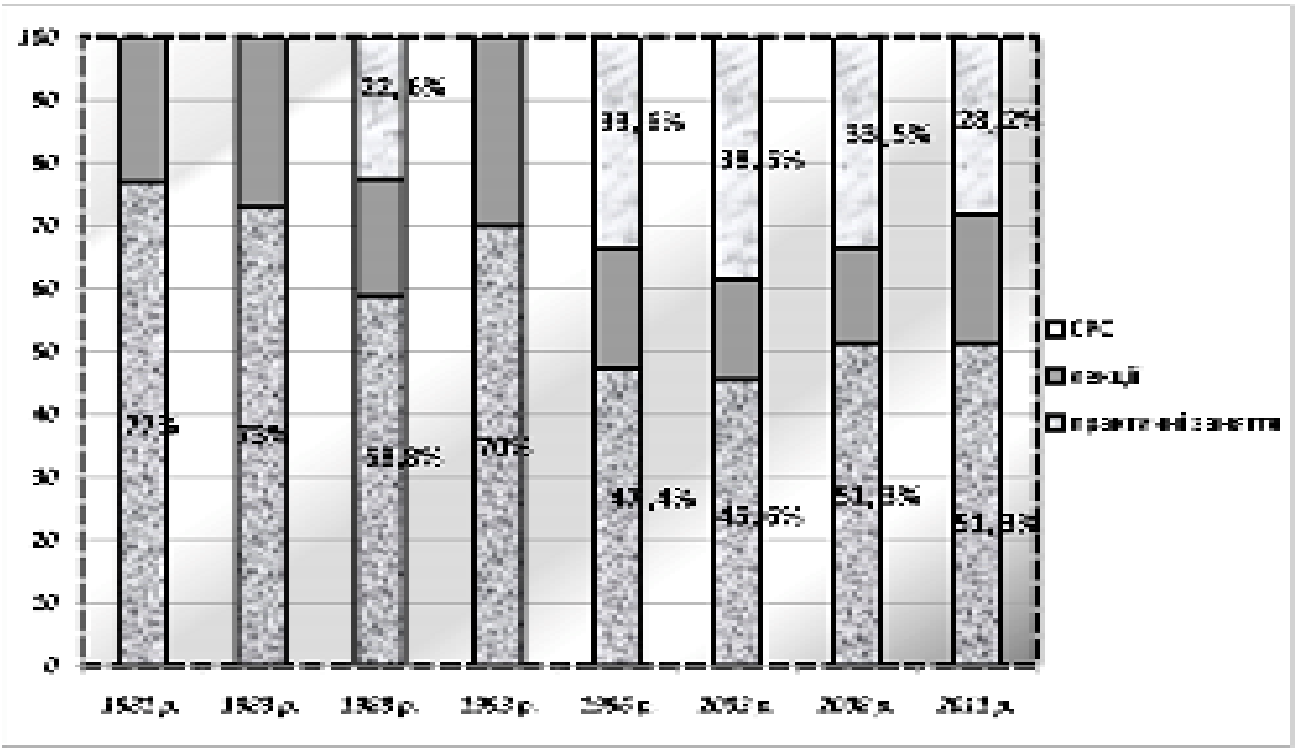

Puc. 2. Динаміка структури академічних годин на кафедрі пропедевтики педіатрії, \%.

2003 р. кількість годин СРС збільшується з 33,6 \% (1996 р.) до 38,5 \% (2003 р.). При цьому на практичні заняття відведено в 2003 р. 45,6 \% годин, тобто практичних занять - 123 години, СРС - 104 години.

Неможливо недооцінювати значення СРС в освіті. Однак зменшення кількості годин по практичних заняттях призводить до значного збільшення об'єму навчального матеріалу (і це не з однієї дисципліни!), необхідного для підготовки до одного практичного заняття. На занятті, тривалість якого 2 академічні години, недостатньо часу для обговорення збільшеного об' єму навчального матеріалу, для опанування студентами збільшеного об' єму практичних навичок по клінічному дослідженню хворого. Наприклад, в 2003 р. для вивчення серцево-судинної системи надавалося 16 академічних годин, тепер - 8 годин.

Відомо, що “повторення - мати навчання". Багаторазове повторення - один з педагогічних прийомів, 
що дозволяє підвищити опанування вивченого матеріалу. Раніше студент систематично працював з кожною темою: на практичному занятті, при підготовці до тематичного заліку, при підготовці до семестрового заліку, при підготовці до заліку з практичних навичок та при підготовці до екзамену. В теперішній час студент має змогу засвоїти кожну тему, яка включає збільшений об'єм, лише на практичному занятті та при підготовці до модульного контролю. На жаль, на практичних заняттях, у зв'язку зі збільшеним об'ємом кожної теми, не тільки не вдається додатково організовувати повторення, додаючи ряд питань 3 раніше вивченого матеріалу (внутрішньодисциплінарні та міждисциплінарні зв'язки), але іноді не достатньо часу на розбір запланованої теми.

В той час, коли кількість годин по СРС збільшується, викладачу не виділено достатнього часу для іiі контролю, сумісного зі студентами аналізу та обговорення результатів протоколів клінічного дослідження хворих, підготовки рефератів та інших сучасних інтерактивних форм організації занять.

У порівнянні з 1993 р. кількість аудиторних годин (практичні заняття та лекціi) у 2011 р. зменшилась на $46 \%$ (майже на половину). На сьогодні у студента звільнилась значна кількість часу. Чи доцільно використовується час студентами? На жаль, недостатньо відпрацьовано механізм, що забезпечує здорову конкуренцію та дозволяє відсіювати невстигаючих студентів.

Коли викладач працює на клінічній кафедрі з 10-13 студентами, а в час проведення медсестринської виробничої практики з 20 - 30 вітчизняними студентами у групі, ефективність навчального процесу значно знижується. Особливо це стосується іноземних студентів, котрі вимагають більшої уваги та індивідуальної роботи з викладачем.

\section{Література}

1. Інтеграція додипломної та післядипломної підготовки лікарів та провізорів - вимога успішної реалізації реформ у сфері охорони здоров'я / Р. О. Моісеєнко, О. К. Толстанов, В. В. Вороненко [та ін.] // Медична освіта. - 2012. - № 2. - С. 6-10.

2. Попередні підсумки запровадження кредитно-модульної системи організації навчального процесу у вищих медичних навчальних закладах та шляхи подальшого удосконалення його організації / В. В. Вороненко, О. П. Волосовець, Ю. С. П'ятницький [та ін.] // Медична освіта. - 2012.№2. - C. $18-22$.
Для підготовки до модульного контролю студентам не виділяється жодного дня, звільненого від занять. У зв'язку з цим знижується рівень підготовки до поточних занять, бо студент змушений готуватися і до модуля з однієї дисципліни, і до практичних занять з інших предметів.

Характеризуючи виробничу практику, особливо медсестринську, необхідно відмітити, що протягом 3 днів іï проходження не уявляється можливим опанувати ті практичні навички, які передбачені програмою.

Висновки. У зв'язку з вищезазначеним, на нашу думку, для кращого опанування студентами вищих медичних навчальних закладів практичних навичок та вмінь доцільно ставити питання про можливість збільшення кількості академічних годин для проведення практичних занять, що крім того дозволить більш ретельно контролювати самостійну роботу студентів.

Необхідно зменшити кількість студентів в академічній групі, що працюють $з$ одним викладачем, для підготовки до модульного контролю (екзамену) виділити хоч би один день, вільний від занять, згрупувати модульні контролі (екзамени) у модульні тижні і проводити їх наприкінці кожного семестру, а не у середині навчального року.

Терміни переддипломної виробничої практичної підготовки, як і навчальної, необхідно переглянути та збільшити з метою підвищення ії якості.

Відповідно до Болонської декларації, раціонально та конструктивно використовуючи ії принципи, кожна країна має право на збереження національних пріоритетів у системі освіти. Ми, викладачі, зобов'язані спрямувати зусилля щодо збереження та примноження престижу ВНЗ України та вітчизняної педіатричної школи.

3. Особливості впровадження кредитно-модульної системи / В. М. Запорожан, В. М. Міщенко, В. Г. Марічереда [та ін.] // Проблеми впровадження кредитно-модульної системи організації навчального процесу : м-ли навч.-метод. конф., присвяченої 110-й річниці університету. - Одеca, 2010.-C. 26-27.

4. UK Bologna Seminar: Using Learning Outcomes. Edinburg, 1-2 July 2004 // www. bologna - bergen 2005.no; Tuning Education Structures in Europe // tuning.unideusto.org / tuningeu. 